Running head: DABROWSKI, PHILOSOPHY, FAITH \& PERSONALITY IDEAL

\begin{abstract}
Kazimierz Dąbrowski’s (1902-1980) five-level theory of personality development, the Theory of Positive Disintegration, is one in which the experience of all emotions is essential for the process of individual growth toward the personality ideal.

In this paper, we introduce the phenomenological and existential influences on Dąbrowski, including the influence of Søren Kierkegaard. We also examine Dąbrowski’s reflections on faith, Christianity, God and human purpose, with particular reference to his unpublished manuscript, Confessions of Faith in Thoughts and Aphorisms.
\end{abstract}

Keywords:

Dąbrowski, phenomenology, Kierkegaard, positive disintegration, philosophy, development, existential, Confessions of faith 
Running head: DABROWSKI, PHILOSOPHY, FAITH \& PERSONALITY IDEAL

\section{Through the Dąbrowski lens: Philosophy, faith and the personality ideal}

The purpose of this paper is to explore the phenomenological and existential influences on Kazimierz Dąbrowski (1902-1980). The philosophical perspectives of phenomenology and existentialism provide a platform for engaging with Dąbrowski's Theory of Positive Disintegration. Specifically addressed is the influence of Søren Kierkegaard on Dąbrowski. This paper will discuss these ideas by examining an unpublished manuscript of Dąbrowski's obtained from the National Archives of Canada. In this important but undated manuscript, Confessions of Faith in Thoughts and Aphorisms, Dąbrowski reflects on many topics including faith, Christianity and human purpose. Despite the manuscript being undated, there are indications within the text that place its composition to between 1972 and 1976.

Dąbrowski identifies Existential Thoughts and Aphorisms as “one of our previous works" (Dąbrowski, n.d., p. 12). This work was published in 1972. Similarly, Dąbrowski’s 1976 paper, On the Philosophy of Development through Positive Disintegration and Secondary Integration, expands ideas introduced in Confessions of Faith in Thoughts and Aphorisms, thus establishing the approximate upper-bound date of composition.

\section{The Phenomenological Movement}

The emergence of the phenomenological movement was heralded through a preparatory phase in the early 1800s; however, it was during the time of Edmund Husserl (1859-1938) that a second phase of phenomenological evolution became more clearly established (Merriam, 2009). For Husserl, phenomenology was "a study of the structure of consciousness, which proceeds by 'bracketing' the objects outside of consciousness itself' (Wrathall \& Dreyfus, 2006, p. 2). Thus, actions are determined by knowledge of cultural heritage, which, by its nature is incomplete. There is a moral responsibility to acknowledge the incompleteness of knowledge and for the sake of intellectual integrity, all ideas and 
Running head: DABROWSKI, PHILOSOPHY, FAITH \& PERSONALITY IDEAL

beliefs must be scrutinized before being accepted as true knowledge (Werkmeister, 1941). Existentialism and phenomenology co-existed, even within the works of Husserl, whose “epistemological considerations...[grew] out of the factual and existential conditions of intellectual integrity and moral responsibility" (Werkmeister, 1941, p. 80). A central theme in phenomenology is that of consciousness, or intention, and the reflection of self within and outside this reality. This theme provides a clear connection from phenomenological thought to a significant element within Dąbrowski's Theory of Positive Disintegration, that being the dynamism of 'subject-object in oneself'. The notions of self-awareness and analysis are also foundational concepts within the Theory of Positive Disintegration and underpin Dąbrowski's concepts of multilevelness, hierarchization of self and the identification of the personality ideal (Dąbrowski, 1996).

Martin Heidegger (1889-1976), whose work featured prominently in the field of existential thought, was also significantly influential within the phenomenological movement, notwithstanding his desire to distance himself from the thinking of Husserl (Speziale \& Carpenter, 2007; Wrathall \& Dreyfus, 2006). Contrasting with Husserl's focus on the nature of consciousness, Heidegger's phenomenological standpoint centered on the human experience of 'being-in-the-world' and the relationships therein (Wrathall \& Dreyfus, 2006). This perspective appears through the dual notion that between every 'mode of being' in the world there is a corresponding 'mode of experiencing' the world. When combined, these 'modes' equate to the totality of existence, and Heidegger's concept of beingness. It is the consideration and investigation of this concept which is, according to Heidegger, the purpose of philosophy. In this way the connection is drawn from phenomenology, to ontology and specifically existential philosophy (Werkmeister, 1941, p. 82).

The work of Husserl and Heidegger also contributed to the 'German phase' of phenomenological emergence by highlighting the development of central concepts: those of 
Running head: DABROWSKI, PHILOSOPHY, FAITH \& PERSONALITY IDEAL

essences, intuiting, and phenomenological reduction. The concept of essence highlights the close links between the work of Dąbrowski and the phenomenological thinkers. We will expand this link later when exploring his thinking in Confessions of Faith in Thoughts and Aphorisms.

The third phase in the evolution of phenomenological thought was led by French philosophers. This included Gabriel Marcel, Jean-Paul Sartre and Maurice Merleau-Ponty, and saw the emergence of the concept of embodiment and further development of the idea of 'being-in-the-world'. Building on their thinking, contemporary phenomenology is used to describe the phenomena of everyday life through the lived and conscious experience of those people living it (Barrasso, 2010; Gibson \& Hanes, 2003; Punch, 2005; Speziale \& Carpenter, 2007; Titchen \& Hobson, 2011). It provides an understanding of how the world might appear to those living in it and the essence of the shared experiences of those people, which are considered the foundational units of common understanding (Speziale \& Carpenter, 2007).

\section{Contemporary Existential Thinking}

Contemporary existential thinking has its roots in the work of Blaise Pascal (16231662), who saw the human experience as a paradox between mind and body. This notion was shared by Søren Kierkegaard (1813-1855). During the twentieth Century, existential thought was divided into two schools: that of a Christian nature where Kierkegaard was positioned, and that of an atheistic nature, encompassing the thinking of Friedrich Nietzsche (18441900), with both maintaining a focus on human freedom, responsibility and authenticity (Wrathall \& Dreyfus, 2006). Importantly for this discussion, Pascal "had an overwhelming religious experience of Jesus the incarnate Christian God" who bore no resemblance to the Hebrew/Christian God as described by philosophers (Dreyfus, 2006, p. 139). From this revelation Pascal began a debate that still continues regarding the existence of, and/or 
Running head: DABROWSKI, PHILOSOPHY, FAITH \& PERSONALITY IDEAL

relationships between, a human essence, the capacity for individual self-definition, and the separation of body and soul. This line of thought also influenced Dąbrowski and can be seen throughout Confessions of Faith in Thoughts and Aphorisms (Dąbrowski, n.d.).

Links between Dąbrowski and Kierkegaard extend across existential and phenomenological inquiry. Jurgen Habermas (1991, as cited in Tilley, 2013) refers to Kierkegaard's 'Either/Or' where the individual takes on responsibility for his or her own existence. Michael Tilley (2013, p. 405) interprets this as meaning:

The self is not created, but it is chosen among a host of other possibilities; the identity of an individual is developed by taking up a particular understanding of the history of the individual and directing one's life according to this historical portrait.

The alliance between existentialism and phenomenology was also demonstrated through the work of Heidegger and Sartre, both of whom continued the traditions of thought established by Kierkegaard and Nietzsche. The influence of Nietzsche's thinking can also been seen in the work of Dąbrowski.

Dąbrowski's contemporaries within the fields of psychology and psychiatry were also influenced by the work of Kierkegaard and Heidegger, notably Ludwig Binswanger, the named "founder of "existential analysis"" (Frie, 2000, p. 108). After initially examining the work of Sigmund Freud, Binswanger turned to the work of Heidegger. Binswanger was the first to identify the importance of Heidegger's work to psychiatry. Binswanger's existential analysis is an approach to psychiatry where "person and world are one. It is thus a question of attempting to understand and explain the human being in the totality of his or her existence, which always includes his or her relationship to others" (Frie, 2000, p. 114). However, while acknowledging the importance of Heidegger's thought, Binswanger was not satisfied with Heidegger's treatment of the social aspect of being human and the inherent part that human interactions play in the achievement of authenticity. In Binswanger's continuing search for 
Running head: DABROWSKI, PHILOSOPHY, FAITH \& PERSONALITY IDEAL

deeper meaning around the social dimension, he turned to the work of Buber and as such moved away from the influence of both Kierkegaard and Heidegger. While the works of Buber and Binswanger did depart from Kierkegaard, Kierkegaard's social ontology and concept of community link his work to the domain of continental religious philosophy and phenomenological inquiry (Tilley, 2013). This conception also relates to Kierkegaard's notion of Existential Dread, where "people become conscious of their own responsibility for their intentions, choices and actions" (Owen, 1994, p. 347).

Dąbrowski portrays the norms of society as largely counter to the personal awareness and motivation that is required as an individual moves through the levels within the Theory of Positive Disintegration. Kierkegaard similarly held little regard for the broader norms of society, suggesting in Two Ages that society is "a demon that forms people in its image but is itself unable to be controlled" (Tilley, 2013, p. 406). Nietzsche also was critical of the influence of society on human development and believed that individuals could not develop their own values while adhering to "dogmas of the day...[which simply stimulate mediocrity, or a] "homogenization...[of] values and ideals" (Tillier, 2008, pp. 109-110). For Nietzsche, one of the strong influences in society, albeit it one he considered less than desirable, was that of the Church. Blind compliance, through the command 'though shalt', along with potential guilt and fear with each deviation, is at the centre of Nietzsche's rejection of religion, thus ensuring the individual has the "right to pursue new values and a freedom for new creation...[through] a continual process of self-overcoming” (Tillier, 2008, p. 113).

Furthering the notion of the individual taking responsibility for his/her own existence, Abraham Maslow, a humanistic psychologist, described existential psychology as "starting from experiential knowledge...Existentialism rests on phenomenology, i.e., it uses personal, subjective experience as the foundation upon which abstract knowledge is built" (Maslow, 1962, p. 9). Extending the thinking of the humanistic psychological movement is 
Running head: DABROWSKI, PHILOSOPHY, FAITH \& PERSONALITY IDEAL

'transpersonal psychology' which "began through the experiential study of meditation, altered states of consciousness, and non-Western epistemology" (Gordon, 2012, p. 81). In this, Gordon also noted (p. 85):

Existential-humanistic or phenomenological knowing, based on the empathic understanding of one's private world of meaning and internal frame of reference associated with the growth-oriented dimension of personality, self-actualization, and the reality of higher states of consciousness, is missing from our models of human development.

However, the inherent spiritual awakening through higher states of consciousness to which she refers is evident in much of the thinking outlined within Dąbrowski's unpublished manuscript, Confessions of Faith in Thoughts and Aphorisms.

\section{Dąbrowski's concept of the 'personality ideal'}

The 'personality ideal' is defined as:

an individual standard against which one evaluates one's actual personality structure. It arises out of one's experience and development. Personality ideal is shaped autonomously and authentically, often in conflict and struggle with the prevalent ideals of society. It is a mental structure which is first intuitively conceived in its broad outline and serves as the empirical model for shaping one's own personality (Dąbrowski, with Kawczak, \& Piechowski, 1970, p. 175).

As the individual gains insight and progresses towards the upper levels of the Theory of Positive Disintegration, thus towards the personality ideal, Dąbrowski describes an element of spiritual awakening, and exemplars of the highest level have been cited in the persons of Socrates, Abraham Lincoln and Mother Teresa (Tillier, 2008). While Dąbrowski outlines complex processes that endow the individual with certain capacities for development, the journey of personality development is a personal one through self-awareness, metacognition 
Running head: DABROWSKI, PHILOSOPHY, FAITH \& PERSONALITY IDEAL

and the spiritual realm. This is articulated throughout Confessions of Faith in Thoughts and Aphorisms.

For Dąbrowski, 'personality ideal' is achieved by reaching level V, or Secondary Integration, within the Theory of Positive Disintegration. Secondary integration is the “integration of all mental functions into a harmonious structure controlled by higher emotions...[It] is the outcome of the full process of positive disintegration" (Dąbrowski, 1972, p. 304). For those individuals with the potential for development, level V is achieved only after immense personal growth facilitated by movement through the levels of development via disintegrative and re-integrative processes, the catalysts for which are found within the three Factors of Development. Personal growth through positive disintegration places the locus of control within the realm of emotional function, rather than intellectual capability (Dąbrowski et al., 1970). A detailed description of the full Theory is beyond the scope of this paper and can be found elsewhere (Harper, Cornish, Smith, \& Merrotsy, 2017; Mendaglio, 2008).

Critical to the development of the personality ideal, and the inherent emergence of an individual's true identity, is the hierachization of values, the development of 'subject-object in oneself' and the capacity to develop oneself from 'what is' to 'what ought to be', which occurs through a process of inner psychic transformation. Fundamental to this process of development is the individual struggle, the unique human experience of growth and conscious differentiation, of "individualized love” (Dąbrowski, n.d., p. 4). Dąbrowski contends that it is through this transformation that full realization of the self occurs. He states that the human "personality is a global phenomenon, a synthesis of all the fundamental psychic qualities, a self-realized unity, self-chosen, self-affirmed and self-educating. In this way it set up the possibility of self-determination and self-creation" (Dąbrowski, p. 18). 
Running head: DABROWSKI, PHILOSOPHY, FAITH \& PERSONALITY IDEAL

\section{Confessions of Faith in Thoughts and Aphorisms}

In keeping with the aforementioned philosophical influences, Confessions of Faith in Thoughts and Aphorisms (Dąbrowski, n.d., p. 3) opens with a commentary on the nature of God's will for His people and questions the much-celebrated notion of 'fusion with God', asking:

Is it the engulfing of us like crumbs without any meaning? Is it to be fusions through a complete shedding of our own individual personality, personal experiences, personal, individual memories, emotional ties, differentiations, and a 'calm and happy' entrance into intellectual, abstract existence, i.e. into a nothingness devoid of personality?

Dąbrowski, a man of Christian faith raised as a Polish Roman Catholic, argues that this is not the intention of God, that this engulfing of individuality is a creation of the institution of the 'Church' which then leads an individual to "re-enter a state of non-existence" (Dąbrowski, n.d., p. 4). Throughout Confessions of Faith in Thoughts and Aphorisms, Dąbrowski is incredulous that perhaps, having travelled the path of positive disintegration and establishing an individualized, differentiated and hard-won personality, the end result is a "non-individualized perfection" (p. 3) and a "devaluation of all aspects of an individualized way toward achieving one's personality" (p. 10), where "ideas...shine in their unchangeability, in their generality, in their perpetuality" (p. 36).

This also represents Dąbrowski's attitude toward the institutionalized indoctrination from the Church and its representation of God. Dąbrowski takes a different view. Having discussed other doctrines, for example Hinduism and Buddhism, he suggests that there is "only one hope - Christ" (Dąbrowski, n.d., p. 4), who led by example in the living of an individual experience and of unconditional love. Dąbrowski considered "that only the thought, example and way of Christ give a positive departure in religions and philosophical systems which occupy themselves with "ultimate matters"' (p. 8). At the core of the meaning 
Running head: DABROWSKI, PHILOSOPHY, FAITH \& PERSONALITY IDEAL

of life, sits love, which through development, "slowly rises to the level of St Paul's 'Letters to the Corinthians' and loses its primitive, impulsive connotation" (p. 39).

While Dąbrowski published all Theory of Positive Disintegration material under his own name, his two works of a more philosophical nature, Existential Thoughts and Aphorisms (1972) and Fragments from the Diary of a Madman (1972) were both published under his pseudonym. Through this separation of content and use of pseudonyms, Kierkegaard's influence is further seen upon Dąbrowski. For Kierkegaard his religious, theologically based material was identified under his own name, however when contemplating aesthetic-philosophical matters, publication occurred under a pseudonym (Elrod, 1973; McKinnon, 1969). At this point it is reasonable consider that had Confessions of Faith in Thoughts and Aphorisms been published, it may have indeed been done so under Dąbrowski’s pseudonym, Paweł, or Paul, Cienin.

In Existential Thoughts and Aphorisms, writing under his pseudonym, Dąbrowski admonishes people for entertaining monologues about God, "and not dialogues with Him. Indeed, there exists saints, but not many of them, who demonstrate comprehensible reasonable dialogue" (Paul Cienin, 1972, p. 25). In this, Dąbrowski is referring to those considered 'saintly' who profess to be 'all-knowing' in regards to God and His wishes for humanity; however, these people do not demonstrate this through their own actions and words. Dąbrowski is referring to an hypocrisy which demands conformity and loss of individualization. Through entries within Confessions of Faith in Thoughts and Aphorisms, Dąbrowski includes Saint John of the Cross and particularly the teachings of Saint Thomas Aquinas within this perspective, where "an intellectual, uncomplicated, undeviating, perpetual God is to engulf us, i.e., to destroy our 'small personalities"” (Dąbrowski, p. 14). The example of Christ provides a regular contrast to the behaviours of the Church and those 
Running head: DABROWSKI, PHILOSOPHY, FAITH \& PERSONALITY IDEAL

therein, whom are perceived to bask in the adulation of the masses and wallow in the trappings of pseudo-glorification and "pseudomystic majesty" (p. 96).

Dąbrowski is also wary of "those who are well situated...[noting that] one can have the badge of a Christian, a Catholic, a priest, a professor, a psychiatrist, a psychologist, a director, a member of this or that 'sublime association' and still be a blackguard” (Dąbrowski, n.d., p. 22). Thus life's purpose and virtue is not associated, in any way, with position or function. Dąbrowski appears quite passionate when he suggests that from within such groups of power comes many a human animal who "stalks its prey, 'scents' its victim which it eventually devours, has no shame, conscience, feeling of guilt, but it does all this...in an intelligent, logical, masked or underhand way" (n.d., pp. 22-23).

Dąbrowski is also adamant that a life "in which circumstances arrange themselves without particular hindrances, a life without suffering and inhibitions, without great joys and disappointments, without sensitive reactions to injustice-is a basically automatic life, coupled to the biological life cycle of the person" (Dąbrowski, n.d., p. 50) and as such will not develop towards the personality ideal. Without the tragic, the challenging, conflicting and the confronting, an individual cannot, will not, experience the inner psychic transformation necessary for multilevel development, or the emergence of a full empathic condition and cannot move towards the personality ideal. Similarly, without these challenges and anxieties, we are not equipped to understand, or experience in its fullness, the tapestry, elation and fulfilment of the process of development. Contentiously, Dąbrowski considers that for the significant majority of people, the concepts captured within the existential or essential questions, along with the nature of multilevelness and multidimensionality will be largely incomprehensible (Dąbrowski, n.d., p. 91).

While this view casts a shroud over the potential of humanity, Dąbrowski is not without hope and recognises the potential for the positive, uplifting and virtuous within individuals. 
Running head: DABROWSKI, PHILOSOPHY, FAITH \& PERSONALITY IDEAL

There is, at the core of every human, the potential for development, which for some can manifest in a dynamic, lifetime's passage, through inner psychic transformation, towards the personality ideal. "Only then does essence emerge from a chaotic or primitive existence, as the relevant form of human existence and as a the principal condition of a meaning for its existence" (Dąbrowski, n.d., p. 26). An auto-deterministic approach is at the core of this thinking, when free will links to our true essence and to the emerging personality, rather than that which is imposed.

In subsequent writing, Dąbrowski expands the understanding of the human essence, which is divided into two qualities: the individual and the social. Individual qualities consists of three elements: first, those aptitudes and talents that form the core meaning or purpose in a person's life without which existence would have no meaning; second, emotional bonds through love and friendship; and third, "the self-conscious identification with oneself, with one's development and with one's perspective for the future" (Dąbrowski, 1976, p. 132). Dąbrowski (p. 132) identifies the essential social qualities as "empathy, social consciousness, authenticity and responsibility" that provide the foundation for all our human interactions and suggests that these are inextricably interconnected with each other. Again Christ provides the exemplar through "consciousness of His own unrepeatable individual identity, and...His constant readiness to serve all the people" (Dąbrowski, 1976, p. 133).

Dąbrowski (n.d., p. 75) places empathy "at the peak of the developmental hierarchy" and suggests that it is synonymous with love. True personality, through authentic development, moves through the "strong universal dynamisms of the sexual instinct [to a true and deep understanding of love, which emerges from] a profound attitude of the emotion of loyalty and a great spiritual need for permanence" (p. 131). Dąbrowski suggests that at level $\mathrm{V}$ the deepest of friendship replaces sexual love and it is this level of love that provides the foundation for a spiritual union. Dąbrowski credits this thinking to Kierkegaard (Dąbrowski, 
Running head: DABROWSKI, PHILOSOPHY, FAITH \& PERSONALITY IDEAL

1996, p. 51). Construction and creation of personality occurs in both the mundaneness of everyday life, and in times of reflection where the process of auto-education is incorporated. This process is documented throughout the Theory of Positive Disintegration (Dąbrowski, 1964).

Dąbrowski (n.d., p. 15) also reflects more closely on an intrinsic existentialist question, that being "what is more fundamental; essence or existence." Dąbrowski's interpretation of the definition postulated through his own experience of the institution of the Church is that 'essence' is "an idea, it is that which is universal, unchanging, integrated, intellectual as opposed to that which is differentiated, emotional, single, individual" (p. 15). This definition, which he considers to be based upon a lack of individual differentiation and the subjugation of emotion - even extracting emotion out of God's love, is quite contrary to Dąbrowski's own perspective. He counters that "the higher we are in development [towards the personality ideal], the more we gain in existence and lose in essence. God is pure existence. Existence is prior to essence and essence cannot be differentiated but in existence" (Dąbrowski, n.d., p. 16). That which is fundamental to human existence and development has its genesis in the recognition of the core qualities of an individual, including emotional bonds of friendship and love; our given gifts and talents; consciousness and sense of identity. The qualitative aspects of these elements remain stable, but do change in a quantitative correlation with development and are essential for an individual to perceive "the meaning of life" (p. 17). Dąbrowski (1976, p. 134) states:

From my point of view, the essence of man is the unity of the conscious, the chosen, the affirmed and the developing major characteristics of individual personalities. In this approach essence is much more important than existence, which...presents something extrinsic to individuality.

Dąbrowski's is a position of "indeterminism, autonomy and authenticity" (p. 18) and it is by this approach to life that an individual, according to Dąbrowski, comes to a relationship 
Running head: DABROWSKI, PHILOSOPHY, FAITH \& PERSONALITY IDEAL

with God. "God...is a God of love and human freedom...[who] loves man and longs for his love, but love out of free will, through the understanding and acceptance of ideals and not just their imposition" (p. 19). In this way "by ourselves - with God's volition and grace as a basis - we acquire our highest possible level...We choose the genuine I; we self-assert and selfeducate ourselves" (p. 56) and move away from "a norm of healthy mediocrity" (p. 85) that facilitates the "squandering away of developmental dynamisms...[and]...mutilates the human psyche" (p. 87). Dąbrowski’s passion for both the value of the autonomous, free-thinking individual and the importance of faith within the journey towards the personality ideal, are clearly articulated through these passages. While Dąbrowski suggests that only God can truly know the human entity, partial knowledge of self and the underpinning personality can be achieved "by a person who is modest, subtle and comprehensively developing" (p. 95).

Dąbrowski further aligns himself with existentialist thought through recurring references to the characteristics and contributions of the existentialists (Paul Cienin, 1972). Specifically, Dąbrowski identifies the writings of Søren Kierkegaard as influential. There are consistent references throughout Dąbrowski's published and unpublished works, not just within Confessions of Faith in Thoughts and Aphorisms, where the influence of Kierkegaard is evident or explicitly mentioned, particularly Kierkegaard's ideas of 'fear and trembling' (de Silentio, 2012) and 'either/or' (Kierkegaard, 2004) where Dąbrowski links Kierkegaard's concepts to expressions of the human condition.

Similarly, philosopher Andrzej Kawczak, in the first chapter of Mental Growth Through Positive Disintegration (Dąbrowski et al., 1970) identifies a relationship between the work of Dąbrowski and "existentialist ethics and existentialist philosophy in general...[and specifically identifies that] Kierkegaard's "Fear and Trembling", "Either/Or" and many other works are masterly descriptions of some states of multilevel disintegration" (Dąbrowski et al., 1970, p. 9). 
Running head: DABROWSKI, PHILOSOPHY, FAITH \& PERSONALITY IDEAL

Dąbrowski uses the term 'either/or' to depict the inner struggle or conflict within the consciousness of an individual, as choices and decisions are made regarding actions, values, desires, "the struggle between good and evil, with the tragedy-swollen feeling of the necessity of selecting and deciding" (Dąbrowski, 2015, p. 31).

The other significant and often-referenced idea from the work of Kierkegaard is that of 'fear and trembling'. Dąbrowski, for example, suggests that the human experience of guilt is akin to 'fear and trembling' especially when the guilt response relates to one's own awareness of not functioning at the highest level of development. At this point there remains a pull towards the lower level while developing a consciousness around the upper levels and the personality ideal. This occurs through self-education, or the "process of working out the personality in one's inner self" (Dąbrowski, 1964, p. 62) where the hierarchization of values becomes clearer; however, the inner conflict between the pull towards lower levels and the yearning for self-perfection culminates in this state of flux where Dąbrowski draws the comparison with 'fear and trembling'. There is a sense of anxiety that accompanies this state; however, it is the 'fear and trembling' within this level of anxiety that provides the potential stimulus for transformation and development, specifically it is "characteristic of the first stage of multilevel development (i.e. spontaneous multilevel disintegration, or level III)" (Dąbrowski, 1972, p. 200). Dąbrowski also credits Kierkegaard with a number of noteworthy contributions, including articulating "the esthetical, ethical and religious phases" within the human development process (Paweł Cienin, 1972, p. 66), of having, along with SaintExupéry, an obsession with "absolute love" (Dąbrowski, 1972, p. 140), and of providing a perception of humanity that "involves hierarchization of values and a developmental transition to higher stages of life" (Dąbrowski, 1973, p. 76).

So for Dąbrowski, the 'true' essence of humanity, of faith, spirituality, of Christ, is tied inextricably to the questions and views identified within both phenomenology and 
Running head: DABROWSKI, PHILOSOPHY, FAITH \& PERSONALITY IDEAL

existentialism. The existential thinkers Kierkegaard and Nietzsche had a significant influence on Dąbrowski as is apparent in his frequent references to their work. This is also true within Confessions of Faith in Thoughts and Aphorisms, in which there are multiple direct references to Kierkegaard and his writings. Dąbrowski's unpublished manuscript also illuminates the importance of faith, spirituality and the place of God in his thinking on humanity, individual development and the personality ideal and ultimately, the totality of human purpose. It is these lofty issues and their practical outworking within the development of human personality that are addressed by Dąbrowski in his Theory of Positive Disintegration. 
Running head: DABROWSKI, PHILOSOPHY, FAITH \& PERSONALITY IDEAL

\section{References}

Barrasso, J. (2010). Qualitative approaches to research. In G. LoBiondo-Wood \& J. Haber (Eds.), Nursing research: Methods, critical appraisal and utilization (pp. 100-113). St. Louis, MO: Mosby/Elsevier.

Cienin, P. (1972). Existential thoughts and aphorisms. London, UK: Gryf.

Cienin, P. (1972). Fragments from the diary of a madman. London, UK: Gryf.

Dąbrowski, K. (1964). Positive dinsintegration. Boston, MA: Little, Brown \& Company.

Dąbrowski, K. (1972). Psychoneurosis is not an illness. London, UK: Gryf.

Dąbrowski, K. (1973). The dynamics of concepts. London, UK: Gryf.

Dąbrowski, K. (1976). On the philosophy of development through positive disintegration and secondary integration. Dialectics and Humanism, 3(4), 131-144.

Dąbrowski, K. (1996). Multilevelness of emotional and instinctive functions. Lublin, Poland: Towarzystwo Naukowe Katolickiego Uniwersytetu Lubelskiego.

Dąbrowski, K. (2015). Personality-shaping through positive disintegration. Otto, NC: Red Pill Press.

Dąbrowski, K. (n.d.). Confessions of faith in thoughts and aphorisms. Department of Psychology. University of Alberta. Unpublished, National Archives of Canada. MG 30 B 88, Vol. 1.

Dąbrowski, K., with Kawczak, A., \& Piechowski, M. M. (1970). Mental growth through positive disintegration. London, UK: Gryf.

de Silentio, J. (2012). Fear and trembling Retrieved from www.amazon.com

Dreyfus, H. L. (2006). The roots of existentialism. In H. L. Dreyfus \& M. A. Wrathall (Eds.), A companion to phenomenology and existentialism (pp. 137-161). Malden, MA: Blackwell. 
Running head: DABROWSKI, PHILOSOPHY, FAITH \& PERSONALITY IDEAL

Elrod, J. W. (1973). The self in Kierkegaard's pseudonyms. International Journal for Philosophy of Religion, 4(4), 218-240.

Frie, R. (2000). The existential and the interpersonal: Ludwig Binswanger and Harry Stack Sullivan. Journal of Humanistic Psychology, 40(3), 108-129. doi:10.1177/0022167800403009

Gibson, S. K., \& Hanes, L. A. (2003). The contribution of phenomenology to HRD research. Human Resource Development Review, 2, 181-205. doi:10.1177/1534484303002002005

Gordon, S. (2012). Existential time and the meaning of human development. The Humanistic Psychologist, 40(1), 79-86. doi:10.1080/08873267.2012.643691

Harper, A. J., Cornish, L., Smith, S., \& Merrotsy, P. (2017). Through the Dąbrowski lens: A fresh examination of the Theory of Positive Disintegration. Roeper Review, 39(1). doi:10.1080/02783193.2016.1247395

Kierkegaard, S. (2004). Either/Or: A fragment of life V. Eremita (Ed.) Retrieved from www.amazon.com

Maslow, A. H. (1962). Toward a psychology of being. Princeton, NJ: Van Nostrand.

McKinnon, A. (1969). Kierkegaard's pseudonyms: A new hierarchy. American philosophical quarterly (Oxford), 6(2), 116-126.

Mendaglio, S. (Ed.) (2008). Dabrowski's Theory of Positive Disintegration. Scottsdale, AZ: Great Potential Press.

Merriam, S. B. (2009) Qualitative research: A guide to design and implementation (pp. 2138). San Francisco, CA: Jossey-Bass.

Owen, I. R. (1994). Introducing an existential-phenomenological approach. Part 2-theory for practice. Counselling Psychology Quarterly, 7(4), 347-347. 
Running head: DABROWSKI, PHILOSOPHY, FAITH \& PERSONALITY IDEAL

Punch, K. F. (2005). Some central issues Introduction to social research: Quantitative and qualitative approaches (pp. 14-31). London, UK: Sage.

Speziale, H. J. S., \& Carpenter, D. R. (Eds.). (2007). Phenomenology as method (4th ed.). Philadelphia, PA: Lippincott Williams.

Tilley, M. (2013). Kierkegaard and recent continental philosophy of religion. Philosophy Compass, 8(4), 400-408. doi:10.1111/phc3.12020

Tillier, W. (2008). Philosophical aspects of Dabrowski's Theory of Positive Disintegration. In S. Mendaglio (Ed.), Dąbrowski's Theory of Positive Disintegration (pp. 101-121). Scottsdale, AZ: Great Potential Press.

Titchen, A., \& Hobson, D. (2011). Phenomenology. In B. Somekh \& C. Lewin (Eds.), Research methods in the social sciences. New Delhi, India: Vistaar.

Werkmeister, W. H. (1941). An introduction to Heidegger's "Existential Philosophy". Philosophy and Phenomenological Research, 2(1), 79-87. doi:10.2307/2102674

Wrathall, M. A., \& Dreyfus, H. L. (2006). A brief introduction to phenomenology and existentialism. In H. L. Dreyfus \& M. A. Wrathall (Eds.), A companion to phenomenology and existentialism (pp. 1-6). Malden, MA: Blackwell. 